6-9-2010

\title{
Who Cares? The Role Of Job Involvement In Psychological Contract Violation
}

Jason S. Stoner

Ohio University, stonerj@ohio.edu

Vickie C. Gallagher

Cleveland State University, v.c.gallagher@csuohio.edu

Follow this and additional works at: https://engagedscholarship.csuohio.edu/bus_facpub

Part of the Business Administration, Management, and Operations Commons, Human Resources Management Commons, Industrial and Organizational Psychology Commons, and the Labor Relations Commons

How does access to this work benefit you? Let us know!

\section{Publisher's Statement}

This is the accepted version of the following article: Stoner, J.S. \& Gallagher, V.C. (2010). Who cares? The role of job involvement in psychological contract violation. Journal of Applied Social Psychology, 40(6), 1490-1514. doi:10.1111/j.1559-1816.2010.00626.x, which has been published in final form at http://onlinelibrary.wiley.com/doi/10.1111/j.1559-1816.2010.00626.x/ abstract

\section{Original Published Citation}

Stoner, J.S. \& Gallagher, V.C. (2010). Who cares? The role of job involvement in psychological contract violation. Journal of Applied Social Psychology, 40(6), 1490-1514. doi:10.1111/j.1559-1816.2010.00626.x

This Article is brought to you for free and open access by the Monte Ahuja College of Business at EngagedScholarship@CSU. It has been accepted for inclusion in Business Faculty Publications by an authorized administrator of EngagedScholarship@CSU. For more information, please contact library.es@csuohio.edu. 


\title{
Who Cares? The Role of Job Involvement in Psychological Contract Violation
}

\author{
JASON S. STONER ${ }^{1}$ \\ Management Systems \\ College of Business \\ Ohio University
}

\author{
Vickie C. Gallagher \\ Department of Management \\ College of Business \\ Northern Kentucky University
}

\begin{abstract}
This study examined survey data from full-time employees employed in a variety of occupations. We empirically examined how psychological involvement with one's job affects reactions to psychological contract violation. Data for control variables (i.e., age, gender, organizational tenure), the independent variable (i.e., psychological contract violation), and the moderator (i.e., job involvement) were taken at Time 1; and dependent variables (i.e., depressed mood at work, turnover intention) were taken at Time 2. Results illustrated that job involvement was an important construct in understanding individuals' negative reactions to psychological contract violations. Implications and limitations are discussed, and suggestions for future research are offered.
\end{abstract}

Why do some individuals seem more adversely affected by mistreatment from their employing organizations than do others? Why do some individuals seem indifferent to organizational injustice? Why do some individuals seem to be unscathed by pay reductions, benefit cuts, promotion pass-overs, and so forth? Researchers in the area of psychological contracts have proposed and illustrated that individual differences, such as career motives, may influence perceptions and reactions to contract violation (Robinson \& Rousseau, 1994; Rousseau, 1990).

The present paper extends this line of thinking by exploring empirically how job involvement affects the relationship between psychological contract violation and depressed mood at work, and between psychological contract violation and turnover intention. We argue that individuals with high job involvement will react differently to psychological contract violation than will individuals who have low job involvement. The two competing theoretical perspectives of cognitive arousal and cognitive dissonance inform our 
research as to the potential benefits as well as the potential negative consequences of high job involvement on the psychological-contract-violation/ outcomes relationship.

Contracts, in a general sense, involve exchange and vary in terms of formality and specificity (Makin, Cooper, \& Cox, 1996). Concerning less formal contracts, perceptions (rather than fact) drive individuals' feelings of implied reciprocal obligations and subsequent contract fulfillment or breach. Hence, in the organizational sciences, psychological contracts have been defined as the implicit beliefs or perceptions as to the terms and conditions of the relationship between employee and employer (Robinson \& Rousseau, 1994). Psychological contract violation occurs when one party in the relationship perceives another as failing to fulfill his or her promised obligation or obligations (Robinson \& Rousseau, 1994).

Based on social exchange theory (e.g., Blau, 1964), Lester, Turnley, Bloodgood, and Bolino (2002) noted that employees' perceptions of psychological contract violations could lead to a host of negative outcomes, such as decreases in extra-role behaviors (Robinson, 1996); neglect (Turnley \& Feldman, 1999b); lower performance (i.e., supervisor ratings; Lester et al., 2002); and higher voluntary turnover, lower levels of trust, and lower job satisfaction (Robinson \& Rousseau, 1994). Research on psychological contract violations has also begun to examine the role of moderating variables. For example, factors such as perceptions of procedural justice during layoffs (Turnley \& Feldman, 1998) and job alternatives (Turnley \& Feldman, 1999b) have been found to moderate the relationship between psychological contract violation and turnover intention.

This paper furthers our understanding of the ill effects of psychological contract violation by exploring the role of job involvement as a moderator. Job involvement involves cognitive preoccupation, engagement, and concern with one's job (Paullay, Alliger, \& Stone-Romero, 1994) whereby individuals identify psychologically with work (Lodahl \& Kejner, 1965). As delineated by Rabinowitz and Hall (1977), we posit that job involvement is an individual difference that is an important component of self-definition, shown to be moderately stable over time (Morrow, 1983).

We will review the literature on psychological contract violations, job involvement, depressed mood at work, and turnover intention. As previously noted, based on two alternative theories, we contend that job involvement is an important moderator that could exacerbate or mitigate the negative effects of perceived contract violation on turnover intention and depressed mood at work. As such, we develop a general research question, which is tested in a sample of full-time workers employed in a variety of occupations. 


\section{Psychological Contract Violation}

Psychological contracts in the workplace are beliefs or perceptions as to the terms and conditions of a relationship between two parties: an employee and the organization (Robinson \& Rousseau, 1994). Psychological contract violations occur when one party in a relationship perceives another to have failed to fulfill promised obligations (Robinson \& Rousseau, 1994). Specifically, a psychological contract is the employee's perception of what has been promised by the organization (e.g., market wages, advancement opportunities, job security), relative to what the employee is expected to give the organization in return (e.g., hard work, loyalty; Lester et al., 2002; Robinson \& Rousseau, 1994). These beliefs are "promises" that both parties have accepted. However, because of the perceptual nature of these contracts, both parties may not necessarily share a common understanding of the terms and conditions of the contract, which is an important notion within the context of psychological contract violations.

While Lester et al. (2002) stressed the importance of considering the employer's perspective and the reciprocal understanding of the psychological contract, our research focuses on the employee's perspective. As stated by Rousseau and Tijoriwala (1998),

In operationalizing the psychological contract, the focal individual can report on beliefs regarding his or her own obligations, as well as beliefs regarding reciprocal obligations owed by another. The individual is the direct source of information regarding the contract because it is the perception of mutuality, not mutuality in fact, that constitutes a psychological contract. (p. 680)

\section{Development of Psychological Contracts}

In order to understand fully how violations can occur, let us briefly review conditions that can contribute to the development of psychological contracts. Antecedents include a wide array of organizational representatives, such as recruiters, human resources specialists, and managers who come into contact with candidates and make promises to employees (Lester et al., 2002). According to Rousseau (2001), each point of contact has potentially "divergent motives that can influence how psychological contracts as a mental model of the employment relationship develop, stabilize, and change" (pp. 524-525). Research has shown that employees vary with regard to their perceptions of who is responsible for the exchange: their immediate 
supervisor, top management, or the firm itself (Rousseau, 1995, 1998). Furthermore, it is believed that upon entrance into an organization, individuals seek new information to clarify vague notions of their contracts (Rousseau, 2001).

To illustrate how divergent perceptions of psychological contracts can develop, Rousseau (2001) described the myriad of views business school professors can have at a single institution with regard to the expected ratio of teaching, executive education, graduate student development, research, and writing. Differences of opinion vary because of the conditions at the time of one's hire: Did the dean or department head convey the importance of each function or role? Furthermore, other organizational changes (e.g., new president, new dean) or economic changes (e.g., budget cuts that alter pay raises) can alter the premises of the psychological contract held between two parties (Rousseau, 2001).

In addition to promises made by organizational representatives, employees may also develop expectations from their perceptions of the organizational culture and their own idiosyncratic (and often idealized) expectations with regard to how they believe the organization operates (Turnley \& Feldman, 1999a). In the case of business school professors, ideological differences can influence one's perception of psychological contracts and expectations, ultimately influencing career emphasis on each component. As Rousseau (2001) explained, these schemas or mental models are developed over time based on experience, social information processing (Salancik \& Pfeffer, 1978), repeated information gathering, and ongoing interactions with one's environment (Robinson, Kraatz, \& Rousseau, 1994). Furthermore, mental models may be difficult to change if, for example, a new dean is hired, asserting a change in focus on one or more of the professor's job duties, such as executive education (Rousseau, 2001). This situation is one of many circumstances that can lead to psychological contract violation.

\section{Outcomes of Psychological Contract Violations}

Psychological contract violations have consequences beyond mere disappointment, often producing feelings of betrayal based on the perceived breach of promise and trust (Robinson \& Rousseau, 1994). Lester et al. (2002) utilized social exchange theory (Blau, 1964) to help explain negative consequences, purporting that when one party believes a violation has occurred, there is a subsequent imbalance perceived to exist in the exchange relationship. This leads to the party's desire to restore balance. A wide array of consequences can result from efforts to restore balance, including diminished performance of in-role behaviors and withholding of extra-role 
behaviors (Robinson, 1996). Other negative consequences include neglect (Turnley \& Feldman, 1999b), turnover, diminished trust, lower job satisfaction (Robinson \& Rousseau, 1994), and emotional exhaustion (Johnson \& O'Leary-Kelly, 2003). In fact, one could argue that serious employee violence is a potential result of perceived breaches, such as was the case in the shooting at the University of Alabama-Huntsville (February 12, 2010) in which a biology professor opened fire on her colleagues, allegedly the result of being denied tenure.

More specifically, perceived psychological contract violations by employers decrease the obligations that employees perceive they have toward their organizations (Robinson et al., 1994). That is, employees perceive a decrease in their transactional obligations (e.g., the obligation to give adequate notice if taking a new job, to protect proprietary company information, and to commit to a minimum of 2 years), as well as their relational obligations (e.g., the obligation to work overtime, to be loyal to the company, and to volunteer for extra-role activities). Furthermore, psychological contract violations are distinct from unmet expectations, such that violations will evoke stronger, more intense negative responses than will simply unmet expectations (Robinson \& Rousseau, 1994). This phenomenon is attributable to the fact that expectations of specific rewards may be unrealistic, whereas violations of reciprocity alter perceptions of respect and codes of conduct (Rousseau, 1989). Psychological contract violations are broken promises that erode trust and induce feelings of betrayal beyond disappointment (Robinson \& Rousseau, 1994).

\section{Role of Mediating and Moderating Variables}

Perceptions of psychological contract violations are exacerbated by a variety of conditions, including situational factors and individual differences. In a longitudinal study, Robinson (1996) found that the strength of the relationship between perceptions of psychological contract violation and contributions to the firm was mediated by a loss of trust, along with unmet expectations. Specifically, as perceptions of violations increased, contributions decreased when these mediators were present. Furthermore, situational factors - such as procedural justice in how layoffs were handled (Turnley \& Feldman, 1998) - altered the relationship between perceptions of psychological contract violations and negative outcomes. Specifically, employees who perceived high procedural justice were less likely to search for new jobs and were more loyal to the organization than were those who perceived low procedural justice. The availability of attractive alternative employment options (also a situational factor) has been found to moderate the 
relationship between psychological contract violations and exit (Turnley \& Feldman, 1999b). However, Conway and Briner (2001) found that work status did not moderate the relationship between psychological contract violations and subsequent outcomes.

In a theoretical paper, Turnley and Feldman (1999a) suggested that individual differences such as negative and positive affect, equity sensitivity, and conscientiousness are likely to be related positively to higher degrees of perceptions of psychological contract violation. Raja, Johns, and Ntalianis (2004) addressed the individual differences proposed by Turnley and Feldman by exploring personality characteristics (i.e., extraversion, conscientiousness, neuroticism, self-esteem, equity sensitivity, locus of control) as they related to perceptions of psychological contract violations among Pakistani workers. Persons high in neuroticism, low in conscientiousness, and high in external locus of control were more likely to perceive psychological breach. Johnson and O'Leary-Kelly (2003) heeded Turnley and Feldman's call for research into individual differences, and found that the relationship between psychological contract breach and emotional exhaustion was mediated by affective cynicism. In sum, the occurrence of these negative consequences is affected by individual differences. In the present paper, we focus on the individual dispositional characteristic of job involvement.

\section{Job Involvement}

Job involvement is defined as the degree to which employees are cognitively preoccupied with, engaged in, and concerned with their present jobs (Paullay et al., 1994) and the degree to which an individual identifies psychologically with work (Lodahl \& Kejner, 1965). According to Brown (1996), "a state of involvement implies a positive and relatively complete state of engagement of core aspects of the self in the job" (p. 235). Individuals become more involved with activities when their jobs provide them the opportunity to fulfill psychological needs (Kanungo, 1979, 1982). Blau (1987) found that job involvement increases as person-environment fit increases. Furthermore, job involvement is considered to be a determinant of organizational effectiveness (Pfeffer, 1994) and individual motivation (Hackman \& Lawler, 1971).

However, when investigated as a moderating variable, the results have been somewhat inconclusive as to how job involvement affects traditional workplace relationships. For instance, several studies (e.g., Jones, James, \& Bruni, 1975; Wiener, Muczyk, \& Martin, 1992) found that supervisor behaviors were more influential on employees who had low job involvement 
(Brown, 1996), indicating that those low in job involvement were more influenced by work environment context than were those high in job involvement. These findings support earlier work summarized by Rabinowitz and Hall (1977) whereby, contrary to expectations, "situational variables seem to have more effect on the attitudes of low job-involvement persons than on high job-involved persons" (p. 285).

Conversely, Frone, Russell, and Cooper (1993) found that job involvement increases negative reactions to workplace pressures, indicating that those high in job involvement are more influenced by work environment context than are those low in job involvement. Such inconsistencies led to the current study, to explore empirically how job involvement influences depressed mood at work and turnover intention associated with psychological contract violation.

\section{Depressed Mood and Turnover Intention}

Depressed mood at work is often conceptualized as a component of psychological strain (e.g., Beehr, 1976; Evans \& Fischer, 1992) and is described as a general feeling of despair toward work (Quinn \& Shepard, 1974). Turnover intention and withdrawal cognition are generally conceptualized as precursors to voluntary turnover (Griffeth, Hom, \& Gaertner, 2000; Richer, Blanchard, \& Vallerand, 2002). Both depressed mood at work and turnover intention are important concepts for organizational researchers to investigate. Specifically, research has noted that employees who are psychologically strained place a greater financial burden on their employing organizations (e.g., increased health care costs, increases in sexual harassment accusations) than do those who are not mentally strained (Danna \& Griffin, 1999). Furthermore, although some voluntary turnover could be good for an organization (e.g., Bluedorn, 1982; Dalton \& Todor, 1979; Staw, 1980), excessive turnover tends to have deleterious effects on firm performance (Abelson \& Baysinger, 1984).

As previously noted, an array of negative organizational outcomes has been tested and correlated with violations of psychological contracts (e.g., turnover, productivity, performance, diminished citizenship behaviors, burnout), and individual differences seemingly play a role in these relationships. Although research has examined the negative main effect of job involvement on turnover intention (e.g., Hackett, Lapierre, \& Hausdorf, 2001; Martin \& Hafer, 1995), research on the moderating effect of job involvement has not exhibited consistent results, encouraging us to examine the relationship between job involvement and psychological contract violation. 


\section{Theoretical Perspectives}

\section{Arousal Cognition}

Based on cognitive-affective and physiological arousal research, scholars have tended to agree that there is an interplay between arousal, cognitive interpretation, and subsequent reactions to environmental stressors (Smith, Everly, \& Johns, 1993). Researchers have explored the arousal-cognition hypothesis, noting that "a person's orientation to dominant information is determined by the magnitude of autonomic nervous system arousal mediated by processing capacity" (Gendolla, 2006, p. 296).

Several studies have illustrated a relationship between cognitive priming and arousal. At the core appear to be individual differences in perceptions of a situation leading to heightened arousal. For instance, Fodor (1985) found that individuals with high need for power engaging in group conflict tended to have higher arousal levels than did individuals with low need for power engaging in group conflict. Griffiths and Dancaster (1995) found that Type A personality led to higher arousal during videogame play than did Type B personality. Branscombe and Wann (1992) found that individuals' identification positively influenced arousal in situations related to the individuals' identification.

The aforementioned studies illustrate that individual differences can influence an individual's arousal level. One characteristic that may impact arousal is involvement. For instance, Ivory and Kalyanaraman (2007) showed that individuals with high levels of involvement with videogames (brought on by technological advances) were more aroused during play than were those who were not involved. We suggest that job involvement may influence arousal in the workplace, although to our knowledge, no studies have explicitly looked at this relationship.

Arousal has also been linked to several outcomes, indicating that individuals are more information sensitive when they are cognitively aroused. For instance, Mather and Nesmith (2008) found that individuals had better memory location of pictures that were cognitively arousing. Hulse, Allan, Memon, and Read (2007) noted that arousal brought on by involvement with an unfolding event led to memory enhancement. Taken together, there is an indication that individuals who are more aroused may be more likely to process and remember information when in an aroused state.

We suggest that job involvement will lead to more arousal, in general, at work. This arousal will influence information processing of workplace events, such as psychological contract violation. Specifically, we suggest that highly involved employees may react more negatively than employees who are not highly involved with their jobs. Individuals with high job involvement 
are more psychologically intimate with their jobs; thus, their levels of awareness of potential imbalances in the contract relationships should be higher than for individuals with low job involvement.

Simply stated, persons who are highly involved with their jobs are more likely to have their antennae up with regard to psychological contract violations. When a violation occurs, they are more likely to suffer greater negative consequences than individuals low in job involvement. This interactive relationship is anticipated because individuals with high job involvement are more likely to feel betrayed - and, subsequently, distrustful of the organization - given that they there are more cognizant of their organizations' implicit obligations.

\section{Cognitive Dissonance}

Conversely, research on cognitive dissonance (e.g., Festinger, 1957) suggests the opposite interactive effects. Dissonance theory proposes that individuals will experience cognitive discomfort (i.e., dissonance) when their actions or behaviors run counter to a subscribed attitude. As such, individuals, in general, will try to reduce dissonance by altering their attitudes to be congruent with their behavior, or by rationalizing away the dissonance (Harmon-Jones, 2000). One way that individuals may rationalize away the dissonance is by downplaying the importance of the sources of dissonance. For instance, in one experiment, Simon, Greenberg, and Brehm (1995) found that participants downplayed the importance of the issue that was causing dissonance.

With regard to the present study, individuals with high job involvement will experience dissonance when they perceive psychological contract violations. Here, we extend the boundaries of cognitive dissonance theory to include employee perceptions of organizational actions. Specifically, as an organization acts counter to how employees expect the organization to act, dissonance will be experienced. Employees may alter their perceptions of what is expected, or reconfigure their psychological contracts. However, the purpose of this study is not to examine empirically the changes in perceptions of psychological contract, but, rather, to explore the reactions to psychological contract violation.

We suggest that it is possible that employees with high involvement will rationalize away the dissonance by downplaying the psychological contract violation or by denying the importance of the violation. This view is in line with previous conceptual work (i.e., Cooper \& Stone, 2000), which proposed that when "a person is exposed to counterattitudinal information on a topic that is a defining attitude for his or her social identity" (p. 241), the person 
may use repression as an ego-defense mechanism. Burris, Harmon-Jones, and Tarpley (1997) noted that one way individuals may reduce dissonance is through transcendence of by "appeal[ing] to superordinate principles" (p. 20). That is, employees with high job involvement may cognitively dismiss the contract violation by justifying the organization's acts.

Specifically, individuals who are highly psychologically involved with their work may, indeed, perceive violations, but their job involvement outweighs the negative implications of perceived contract violations. In other words, because highly involved employees are psychologically invested in the organization, often showing career commitment (Brown, 1996), they may wish to downplay their perceptions of the severity of a violation in an attempt to prevent dissonance. We suggest that individuals high in job involvement may downplay violations in an attempt to protect their sense of self. In this interaction, we expect more severe reactions to psychological contract violation from individuals who are low in job involvement, as compared to those who are high in job involvement.

\section{Summary of Conflicting Views}

Given the previous review of arousal-cognition and cognitive dissonance research, we propose a general research question, rather than a directional hypothesis. Based on arousal-cognition research, individuals high in job involvement are expected to increase their turnover intention as psychological contract violations increase, whereas turnover intention for individuals low in job involvement should remain unaffected by increases in violations. Conversely, based on cognitive dissonance research, individuals low in job involvement will be more likely to increase their turnover intention as a result of psychological contract violations than will individuals high in job involvement. As such, the present paper empirically examines the following research question:

Research Question. Does job involvement exacerbate or mitigate the positive relationship between psychological contract violation and dysfunctional personal and organizational outcomes (i.e., depressed mood at work, turnover intention)?

\section{Method}

Sample

Respondents represented a cross-section of the general working population in a midsized city in the southeastern United States. University students 
assisted in identifying full-time employees who were at least 25 years of age. Students were then responsible for delivering and collecting surveys at two times. This method of data collection is consistent with previous survey research (e.g., Byrne, Kacmar, Stoner, \& Hochwarter, 2005; Treadway et al., 2005). Data were collected at two points in time (1 month apart), and participants were assured that their answers would be kept confidential.

Measures for psychological contract violation, job involvement, age, gender, and organizational tenure were collected at Time 1. One month later, measures for depressed mood at work and turnover intention were collected. Independent and dependent variables were collected 1 month apart to minimize the occurrence of common method variance. Surveys from Time 1 and Time 2 were matched by birthday of the respondent and by name of distributor (as respondent names were not used, in order to provide anonymity and enhance response rates).

A total of 126 respondents ( 72 females, 54 males) were included in the final analyses. Descriptive statistics reveal that the surveyed employees' mean age was 40.4 years $(S D=12.5)$. In addition, their mean organizational tenure was 7.9 years $(S D=7.6)$.

\section{Measures}

Psychological contract violation. Data for psychological contract violation were collected on an 18-item scale developed by Lester et al. (2002). Participants were asked to indicate the level they currently receive from their jobs, relative to the level that they expected to receive, with regard to items such as "Overall benefits package provided" and "Materials and equipment to do my job." Responses were rated on a 5-point scale ranging from 1 (I am receiving much less than $I$ expect) to 5 (I am receiving much more than I expect). The scale was then reversed so that high scale numbers indicate a greater psychological contract violation than do low scale numbers. Coefficient alpha reliability for this scale was .95 .

Job involvement. We used a five-item scale adapted from Lodahl and Kejner's (1965) job involvement scale to measure psychological job involvement. Participants were asked to indicate how they feel about items such as "The most important things that happen to me involve my work," "I'm really a perfectionist about my work," "I am very much involved personally in my work," and "I live, eat, and breathe my job" on a 5-point scale ranging from 1 (strongly disagree) to 5 (strongly agree) scale. Coefficient alpha reliability for this scale was .82 .

Depressed mood at work. Data measuring depressed mood at work were collected using a 10-item scale developed by Quinn and Shepard (1974). 
Participants were asked to indicate how they feel when they think about their jobs, such as "I feel downhearted and blue," and "I am more irritable than usual at work." The items were rated on a 4-point scale ranging from 1 (never) to 4 (often). Coefficient alpha reliability for this scale was .83.

Turnover intention. Turnover intention was measured using a seven-item scale developed by House and Rizzo (1972). Participants were asked to think about how satisfied they are with their jobs and with life in general. They responded to items such as "I will probably look for a new job in the near future," and "I am thinking about quitting my job." The items were rated on a 5-point scale ranging from 1 (strongly disagree) to 5 (strongly agree). Coefficient alpha reliability for this scale was .92 .

Controls. Based on previous research, we controlled for several variables in our statistical analysis. First, age and gender were controlled for because of the relationship between these variables and turnover intention (Hochwarter et al., 2001). For instance, Blau and Lunz (1998) found that age and gender were related to turnover intention such that younger and less satisfied employees were more likely to leave their jobs. Furthermore, in their longitudinal study, these researchers found that men had higher intentions to leave than did women did. Finally, organizational tenure has been conceptually and empirically linked with turnover intention (van Breukelen, van der Vlist, \& Steensma, 2004).

\section{Data Analysis}

To examine the research question, we used hierarchical moderated regression (Cohen \& Cohen, 1983). As noted previously, demographic variables (i.e., age, gender, organizational tenure) were controlled in Step 1 of the regression analyses. Following, in Step 2, the independent variable (i.e., psychological contract violation) was entered into the equation. In Step 3, the main effect of the moderator (i.e., job involvement) was entered into the equation. In the final step, the interactive term (i.e., Psychological Contract Violation $\times$ Job Involvement) of the centered variables was entered into the equation. The final step must be statistically significant and must explain additional variance in the dependent variables over that of the main effects in order to illustrate that job involvement acts as a moderator.

\section{Results}

Bivariate correlations are presented in Table 1. The results from the hierarchical moderated regressions, reported in Table 2, indicate that job 
Table 1

Correlations of Study Variables

\begin{tabular}{|c|c|c|c|c|c|c|}
\hline Variable & 1 & 2 & 3 & 4 & 5 & 6 \\
\hline 1. Age & - & & & & & \\
\hline 2. Gender & .11 & - & & & & \\
\hline $\begin{array}{l}\text { 3. Organizational } \\
\text { tenure }\end{array}$ & $.55 * * *$ & .11 & - & & & \\
\hline 4. PCV & .06 & $.21 * * *$ & .09 & - & & \\
\hline $\begin{array}{l}\text { 5. Job } \\
\text { involvement }\end{array}$ & $.18^{*}$ & $-.21 * * *$ & .09 & $-.37 * * *$ & - & \\
\hline $\begin{array}{l}\text { 6. Depressed } \\
\text { mood at work }\end{array}$ & $-.27 * * *$ & .023 & -.09 & $.44 * * *$ & $-.28 * * *$ & - \\
\hline $\begin{array}{l}\text { 7. Turnover } \\
\text { intention }\end{array}$ & $-.37 * * *$ & .02 & $-.21 *$ & $.46^{* * * *}$ & $-.27 * * *$ & $.62 * * *$ \\
\hline
\end{tabular}

Note. $\mathrm{PCV}=$ psychological contract violation. $N=126$.

$* p<.05$. *** $p<.001$.

involvement moderated the relationship between psychological contract violation and depressed mood at work. First, after age, gender, and organizational tenure were controlled for, psychological contract violation was significantly related to depressed mood at work $(\beta=.44, p<.001)$. However, the moderating variable, job involvement, was not significantly related to depressed mood at work $(\beta=-.11, n s)$. In the final step of analysis, the interaction term of psychological contract violation and job involvement was significant $(\beta=-.18, p<.05)$ and explained an additional 3.1\% $\left(\Delta R^{2}=.031\right)$ of the variance in depressed mood at work.

Furthermore, the results show that job involvement moderated the relationship between psychological contract violation and turnover intention. First, after age, gender, and organizational tenure were controlled for, psychological contract violation was significantly related to turnover intention. However, the moderating variable, job involvement, was not significantly related to turnover intention $(\beta=-.09, n s)$. In the final step of analysis, the interaction term of psychological contract violation and job involvement was significant $(\beta=-.17, p<.05)$ and explained an additional $2.7 \%\left(\Delta R^{2}=.027\right)$ of the variance in turnover intention.

To depict graphically the significant interaction term, we plotted the interactions based on Aiken and West (1991) and used a computer graphing program (Dawson, 2007) to plot two levels of job involvement scores: $1 S D$ 
Table 2

Hierarchical Moderated Regression

\begin{tabular}{|c|c|c|c|c|}
\hline & \multicolumn{2}{|c|}{$\begin{array}{c}\text { Depressed } \\
\text { mood at work }\end{array}$} & \multicolumn{2}{|c|}{$\begin{array}{l}\text { Turnover } \\
\text { intention }\end{array}$} \\
\hline & $\beta$ & $\Delta R^{2}$ & $B$ & $\Delta R^{2}$ \\
\hline \multicolumn{5}{|l|}{ Step 1} \\
\hline Age & $-.24 *$ & & $-.28 *$ & \\
\hline Gender & -.06 & & -.05 & \\
\hline Organizational tenure & .05 & & -.05 & \\
\hline$F_{\text {change }}(3,122)=4.04$ & & $.09 * *$ & & \\
\hline$F_{\text {change }}(3,122)=6.56$ & & & & $.14 * * *$ \\
\hline \multicolumn{5}{|l|}{ Step 2} \\
\hline Psychological contract violation & $.44 * * *$ & & $.42 * * *$ & \\
\hline$F_{\text {change }}(1,121)=29.03$ & & $.18 * * *$ & & \\
\hline$F_{\text {change }}(1,121)=28.57$ & & & & $.17 * * *$ \\
\hline \multicolumn{5}{|l|}{ Step 3} \\
\hline Job involvement & -.11 & & -.09 & \\
\hline$F_{\text {change }}(1,120)=1.16$ & & $.01 *$ & & \\
\hline$F_{\text {change }}(1,120)=0.87$ & & & & .01 \\
\hline \multicolumn{5}{|l|}{ Step 4} \\
\hline Interaction & $-.18 *$ & & $-.17 *$ & \\
\hline$F_{\text {change }}(1,119)=5.38$ & & $.03 *$ & & \\
\hline$F_{\text {change }}(1,119)=4.80$ & & & & $.03 *$ \\
\hline
\end{tabular}

Note. $N=126$.

${ }^{*} p<.05 .{ }^{* *} p<.01 .{ }^{* * *} p<.001$.

above the mean and $1 S D$ below the mean. Under low psychological contract violation conditions, employees high in job involvement had lower levels of depressed mood at work and intention of leaving their jobs, as compared to employees low in job involvement (see Figures 1 and 2). Furthermore, as psychological contract violations increased, so did reported depressed mood at work and turnover intention for employees with low job involvement. However, this relationship does not appear to be as robust for employees high in job involvement, in that their depressed mood at work and turnover intention were relatively the same in high and low psychological contract 


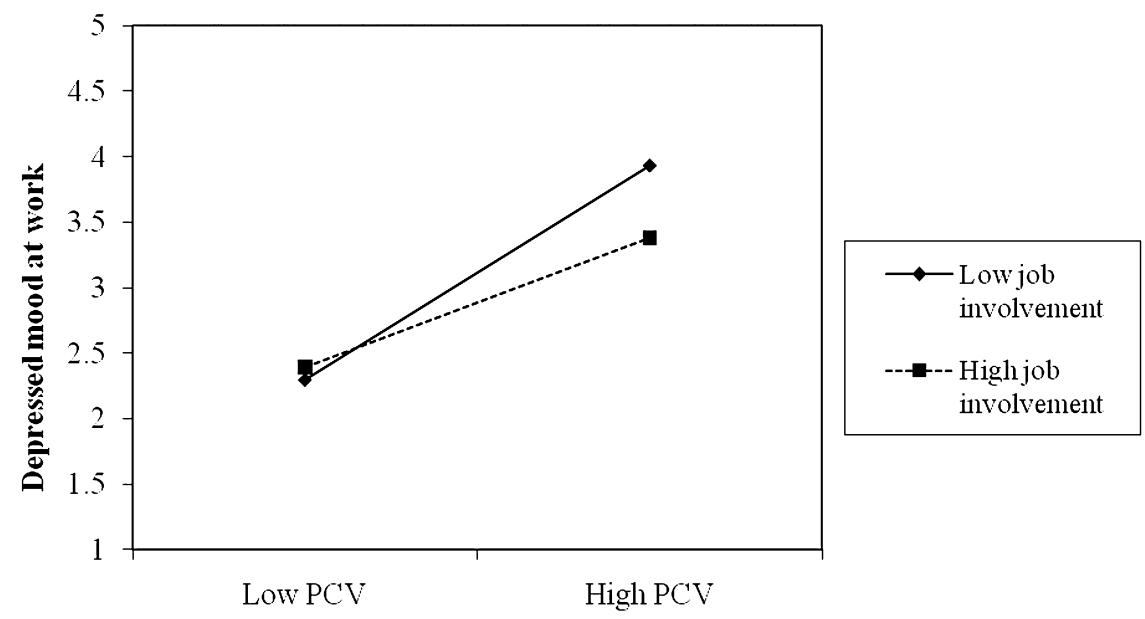

Figure 1. Interactive effects of Psychological Contract Violation $\times$ Job Involvement (moderator) on depressed mood at work.

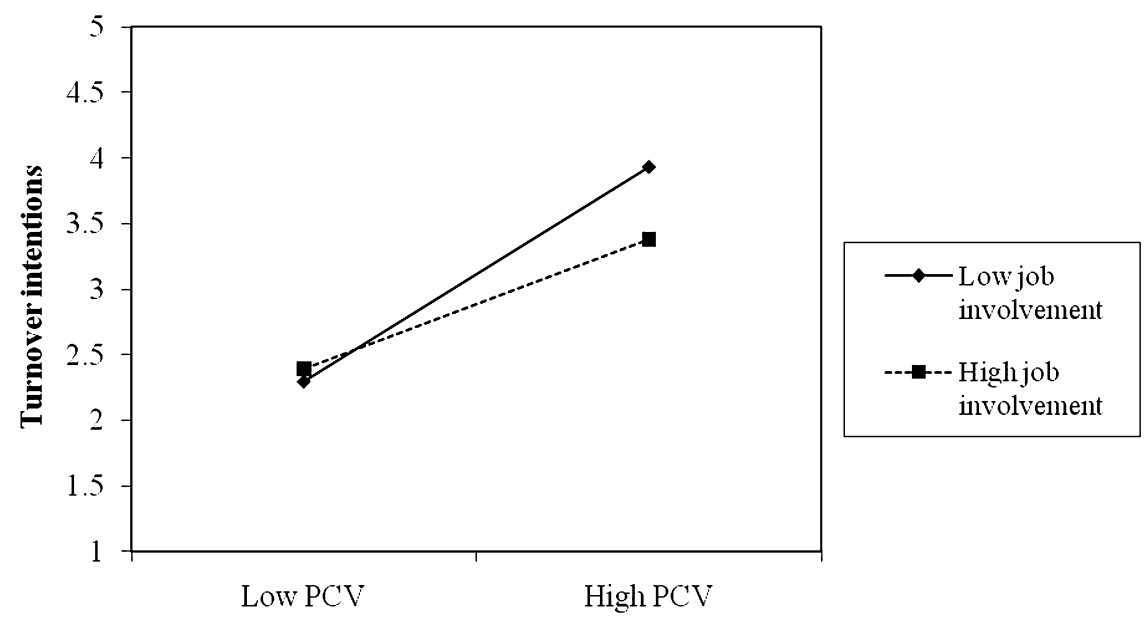

Figure 2. Interactive effects of Psychological Contract Violation $\times$ Job Involvement (moderator) on turnover intention.

violation conditions. Thus, individuals with high job involvement seem to be relatively unaffected by perceptions of psychological contract violation.

To examine further the nature of the interaction, we conducted a series of simple slope analyses. For each dependent variable, the job involvement 
variable was partitioned into high and low subgroups, which were determined by the mean $\pm 1 S D$ (for high and low subgroups, respectively). Next, we conducted a simple regression. In order to conclude that the dependent variables change as psychological contract violations increase, and in order to assess the nature and direction of the relationship, the simple regression must be significant.

When psychological contract violation was regressed on depressed mood at work, utilizing the low job involvement subgroup, depressed mood at work increased as psychological contract violations increased $(\beta=.56$, $p<.05 ; N=23$ ). Furthermore, for the high job involvement subgroup, depressed mood at work did not change as psychological contract violations increased $(\beta=.35, n s ; N=22)$. That is, individuals low in job involvement experienced increases in depressed mood at work as a result of psychological contract violations, yet individuals high in job involvement did not experience any change in depressed mood at work as psychological contract violations increased.

Furthermore, when psychological contract violation was regressed onto turnover intention utilizing the low job involvement subgroup, turnover intention increased as psychological contract violations increased $(\beta=.73$, $p<.001 ; N=22)$. For the high job involvement subgroup, turnover intention did not change as psychological contract violations increased $(\beta=.29, n s$; $N=22$ ). That is, individuals low in job involvement reported stronger levels of turnover intention as psychological contract violations increased, whereas those high in job involvement did not change their turnover intention as psychological contract violations increased.

\section{Discussion}

The results from our survey data show that psychological contract violations interacted with job involvement. After graphing the interactions and conducting a series of simple slope analysis, it was revealed that negative reactions to psychological contract violations (i.e., depressed mood at work, turnover intention) increased for individuals low in job involvement; however, attitudes remained unchanged for those high in job involvement. Thus, to answer the research question proposed earlier in this paper, job involvement tends to mitigate the relationship between psychological contract violations and depressed mood at work, as well as the relationship between psychological contract violations and turnover intention.

Our findings lend support to cognitive dissonance theory such that those who are psychologically involved and invested in their work tend to remain unscathed by psychological contract violations. That is, although they may 
perceive breaches in the workplace, those who are psychologically involved downplay the significance of psychological contract violations, while individuals who are not psychologically involved in their work react adversely to violations. Our findings support the notion that individuals who are less psychologically involved in their work react more severely to psychological contract violations, as compared to individuals who are more psychologically involved with their work.

One plausible explanation is that individuals high in job involvement may be more concerned about issues relevant to their job performance (e.g., positive feedback on a job well done), rather than implicit assumptions (e.g., psychological contract violations). This view is in line with previous cognitive dissonance research that has proposed that individuals may reduce dissonance by minimizing the importance of the issue causing dissonance (e.g., Simon et al., 1995) or justifying the dissonance with external information (e.g., Brock \& Buss, 1962; Stalder \& Baron, 1998). In the current study, we suggest that job involvement may also initiate rationalizations of incongruences in order to minimize cognitive dissonance.

Beyond the data reported in this study, there are alternative explanations for why individuals high in job involvement did not increase their turnover intention and depressed mood at work as a result of psychological contract violations. It is possible that those with high job involvement have a better understanding of organizational happenings because they may, indeed, pay attention to what the organization is doing or thinking. Individuals high in job involvement may have additional information or inside information as to why psychological contract violations have occurred, thereby having a greater means for justifying the need for adjustments in policies. Although "understanding" was not measured in the current study, this variable could provide an alternative explanation for why individuals high in job involvement did not experience increases in turnover intention and depressed mood at work traditionally associated with contract violation.

Furthermore, our findings build on previous empirical research regarding job involvement's impact on employees' psychological well-being. As first noted by Rabinowitz and Hall (1977), and later confirmed in a meta-analysis by Brown (1996), highly involved individuals do not appear to suffer from increased levels of stress, anxiety, or somatic health complaints in the workplace. These results can be explained by examining past research on factors that mitigate the negative consequences of psychological contract violation.

Specifically, our results could be explained by the assertion that initial trust moderates the relationship between psychological contract violation and various negative outcomes (Dirks \& Ferrin, 2001; Mishra \& Spreitzer, 1998; Robinson, 1996). That is, although trust was not measured, it could be that employees with high job involvement have a high amount of initial trust 
in their organization. Therefore, this trust moderates the relationships, and employees high in job involvement believe that organizations have good reasons for violations. Conversely, employees low in job involvement will become more distraught under violation conditions because they lack faith that their company is on their side. Thus, the significant interaction of job involvement and psychological contract violation on depressed mood at work and turnover intention does hold several important implications that warrant discussion.

\section{Implications}

The findings reported in this paper add to several bodies of literature. Our findings support previous research (Robinson \& Rousseau, 1994; Rousseau, 1990), which notes that individual differences will influence the impact of psychological contract violations. From the results, we extend this line of research by concluding that being psychologically involved in one's job will offset the negative repercussions normally associated with psychological contract violation. Furthermore, our findings support previous research (Brown, 1996) by providing additional evidence that individuals who are highly involved in their jobs are more resilient to organizational stressors. Taken together, several managerial implications come to light.

Knowledge of an employee's perceptions of a psychological contract is vital to the health and well-being of both the organization and the individual. Enhanced understanding can help organizations to communicate their expectations and what they have to offer the employee more effectively (Lester et al., 2002), thereby reducing the negative consequences of perceptions of breach of psychological contract. A more explicit, open discussion, or a more transparent presentation of the psychological contract is vital (Herriot \& Pemberton, 1995). Psychological contracts that are discussed more explicitly can help individuals to feel some sense of control over their destiny, thereby reducing uncertainty for both parties (Rousseau, 1995) and subsequently reducing stress (Makin et al., 1996). Rousseau (2003) suggested that realistic job previews can help facilitate mutuality, yet other factors can hinder shared understanding, such as relational factors (e.g., relative differences in experience, power, and expertise), as well as social differences between parties that minimize common frames of reference. In fact, Robinson and Wolfe Morrison (2000) found that perceived contract breach was more likely when employees had not experienced a formal socialization process and when employees had little interaction with the organizational agents prior to hire.

We argue that organizations should encourage company representatives to represent the culture, norms, and expectations accurately. As Rousseau 
(2001) advocated, perceptual accuracy hinges on the ability to communicate each party's goals, constraints, and contingencies. Recruiters are not inherently motivated to provide accurate information (Porter, Lawler, \& Hackman, 1975) and, therefore, are less likely to provide realistic job previews (Wanous, 1977). As Robinson and Rousseau (1994) concluded, "Overselling a job's features can be compounded with subjective interpretation of what the promised 'great' job actually entails" (p. 255).

Our findings also suggest that employees who have high job involvement may be less susceptible to workplace stressors than employees who have low job involvement. The current study's results could be used to manage employees better after a psychological contract has occurred. That is, managers could anticipate that their employees with low job involvement are more likely to be negatively affected by a psychological contract violation than employees who "live their jobs." Thus, managers may need to spend more time explaining the reasons and justifications for perceived psychological contract violations to individuals who are relatively emotionally removed from their jobs.

\section{Limitations and Future Research Directions}

The present study is not without limitations. One limitation is that it represents only the employee's perspective, rather than also including the employer's perspective of contract violation, as suggested and researched by other scholars (Guest \& Conway, 2002; Lester et al., 2002; Tekleab \& Taylor, 2003). In addition, while common method variance was reduced by collecting the independent variable (i.e., psychological contract violation and job involvement at Time 1) separate from the dependent variables (i.e., depressed mood at work and turnover intention at Time 2), the data cannot be interpreted as longitudinally studying the evolving nature of one's relationship with one's employer. Finally, our data were collected with the assistance of university students, lending to a lack of control over the sample selection process.

The present research supports job involvement as a moderator of the psychological-contract-violation/outcome relationship. As noted by Makin et al. (1996), as well as other scholars (Robinson et al., 1994), the psychological contract is in a constant state of change. Changes in organizational structure, either physically or socially, can affect perceptions of balance. As suggested by Rousseau (2001), "since psychological contract formation typically is a process, not a one-time occurrence, the quality of the relationship over time will shape mutuality" (p. 537). As organizations evolve, the scope of the psychological contract may indeed broaden, making continued 
research in this area important for organizational scientists and practicing professionals. In the future, researchers may wish to conduct a longitudinal study of the variables from the current study.

We suggest that future research should investigate alternative models with the variables presented in the current study. For instance, we focused on the moderating effect of job involvement on the psychological-contractviolation/outcome (i.e., turnover intention and depressed mood at work) relationship. However, a mediating model should also be explored. It is possible that job involvement actually influences perceptions of psychological contracts or that psychological contract violations actually influence job involvement.

This study was designed to test the moderating effect of job involvement on the psychological-contract-violation/turnover-intention relationship. Two differing perspectives (i.e., arousal-cognition and cognitive dissonance) were reviewed to illustrate that the effect of job involvement could influence the relationship in opposing manners. Results from 126 working individuals provided support for the cognitive dissonance perspective, in that individuals high in job involvement did not increase their turnover intention as psychological contract violations increased, while individuals low in job involvement did increase their turnover intention. These findings highlight the important mitigating effect that job involvement has on the psychological-contract-violation/turnover-intention relationship, answering the call for more research into individual differences (e.g., career motives) that are believed to influence perceptions and reactions to contract violation (Robinson \& Rousseau, 1994; Rousseau, 1990).

\section{References}

Abelson, M. A., \& Baysinger, B. D. (1984). Optimal and dysfunctional turnover: Toward an organizational level model. Academy of Management Review, 9, 331-341.

Aiken, L. S., \& West, S. G. (1991). Multiple regression: Testing and interpreting interactions. Newbury Park, CA: Sage.

Beehr, T. A. (1976). Perceived situational moderators of the relationship between subjective role ambiguity and role strain. Journal of Applied Psychology, 61, 35-40.

Blau, G. J. (1987). Using a person-environment fit model to predict job involvement and organizational commitment. Journal of Vocational Behavior, 30, 240-257.

Blau, G., \& Lunz, M. (1998). Testing the incremental effect of professional commitment on intent to leave one's profession beyond the effects of 
external, personal, and work-related variables. Journal of Vocational Behavior, 52, 260-269.

Blau, P. M. (1964). Exchange and power in social life. New York: Wiley.

Bluedorn, A. C. (1982). Managing turnover strategically. Business Horizons, $25,6-12$.

Branscombe, N. R., \& Wann, D. L. (1992). Physiological arousal and reactions to out-group members during competitions that implicate an important social identity. Aggressive Behavior, 18, 85-93.

Brock, T. C., \& Buss, A. H. (1962). Dissonance, aggression, and evaluation of pain. Journal of Abnormal and Social Psychology, 65, 197-202.

Brown, S. B. (1996). A meta-analysis and review of organizational research on job involvement. Psychological Bulletin, 20, 235-255.

Burris, C. T., Harmon-Jones, E., \& Tarpley, W. R. (1997). "By faith alone": Religious agitation and cognitive dissonance. Basic and Applied Social Psychology, 19, 17-31.

Byrne, Z., Kacmar, C., Stoner, J., \& Hochwarter, W. (2005). The relationship between perceptions of politics and depressed mood at work: Unique moderators across three levels. Journal of Occupational Health Psychology, 10, 330-343.

Cohen, J., \& Cohen, P. (1983). Applied multiple regression/correlation analysis for the behavioral sciences (2nd ed.). Hillsdale, NJ: Lawrence Erlbaum.

Conway, N., \& Briner, R. B. (2001). Full-time versus part-time employees: Understanding the links between work status, the psychological contract, and attitudes. Journal of Vocational Behavior, 61, 279-301.

Cooper, J., \& Stone, J. (2000). Cognitive dissonance and the social group. In D. J. Terry \& M. A. Hogg (Eds.), Attitudes, behavior, and social context: The role of norms and group membership (pp. 227-244). Mahwah, NJ: Lawrence Erlbaum.

Dalton, D. R., \& Todor, W. D. (1979). Turnover turned over: An expanded and positive perspective. Academy of Management Review, 4, 225-235.

Danna, K., \& Griffin, R. W. (1999). Health and well-being in the workplace: A review and synthesis of the literature. Journal of Management, 25, 357-384.

Dawson, J. (2007). Interpreting interaction effects. Retrieved October 1, 2007, from www.jeremydawson.co.uk/slopes.htm

Dirks, K. T., \& Ferrin, D. L. (2001). The role of trust in organizational settings. Organization Science, 12, 450-467.

Evans, B. K., \& Fischer, D. G. (1992). A hierarchical model of participatory decision-making, job autonomy, and perceived control. Human Relations, 45, 1169-1189.

Festinger, L. (1957). A theory of cognitive dissonance. Stanford, CA: Stanford University Press. 
Fodor, E. (1985). The power motive, group conflict, and physiological arousal. Journal of Personality and Social Psychology, 49, 14081415.

Frone, M. R., Russell, M., \& Cooper, M. L. (1993). Relationship of workfamily conflict, gender, and alcohol expectancies to alcohol use/abuse. Journal of Organizational Behavior, 14, 545-558.

Gendolla, G. H. E. (2006). Static thinking as cognitive coping with performance difficulties: The role of motivation and "arousal." Anxiety, Stress, and Coping: An International Journal, 19, 293-307.

Griffeth, R. W., Hom, P. W., \& Gaertner, S. (2000). A meta-analysis of antecedents and correlates of employee turnover: Update, moderator tests, and research implications for the next millennium. Journal of Management, 26, 463-488.

Griffiths, M. D., \& Dancaster, I. (1995). The effect of Type A personality on physiological arousal while playing computer games. Addictive Behavior, $20,543-548$.

Guest, D. E., \& Conway, N. (2002). Communicating the psychological contract: An employer perspective. Human Resource Management Journal, $12,22-38$.

Hackett, R. D., Lapierre, L. M., \& Hausdorf, P. A. (2001). Understanding the links between work commitment constructs. Journal of Vocational Behavior, 58, 392-413.

Hackman, J. R., \& Lawler, E. E., III. (1971). Employee reactions to job characteristics. Journal of Applied Psychology, 55, 259-286.

Harmon-Jones, E. (2000). An update on cognitive dissonance theory, with a focus on the self. In A. Tesser, R. B. Felson, \& J. M. Suls (Eds.), Psychological perspectives on self and identity (pp. 119-144). Washington, DC: American Psychological Association.

Herriot, P., \& Pemberton, C. (1995). New deals: The revolution in managerial careers. Chichester, UK: Wiley.

Hochwarter, W. A., Ferris, G. R., Canty, A. L., Frink, D. D., Perrewé, P. L., \& Berkson, H. M. (2001). Reconsidering the job performance-turnover relationship: The role of gender in form and magnitude. Journal of Applied Social Psychology, 31, 2357-2377.

House, R. J., \& Rizzo, J. R. (1972). Toward the measurement of organizational practices: Scale development and validation. Journal of Applied Psychology, 56, 388-396.

Hulse, L. M., Allan, K., Memon, A., \& Read, J. D. (2007). Emotional arousal and memory: A test of the poststimulus processing hypothesis. American Journal of Psychology, 120, 73-90.

Ivory, J. D., \& Kalyanaraman, S. (2007). The effects of technological advancement and violent content in video games on players' feelings of 
presence, involvement, physiological arousal, and aggression. Journal of Communications, 57, 532-555.

Johnson, J. L., \& O'Leary-Kelly, A. M. (2003). The effects of psychological contract breach and organizational cynicism: Not all social exchange violations are created equal. Journal of Organizational Behavior, 24, 627 647.

Jones, A. P., James, L. R., \& Bruni, J. R. (1975). Perceived leadership behavior and employee confidence in the leader as moderated by job involvement. Journal of Applied Psychology, 60, 146-149.

Kanungo, R. N. (1979). The concept of alienation and involvement revisited. Psychological Bulletin, 86, 119-138.

Kanungo, R. N. (1982). Measurement of job and work involvement. Journal of Applied Psychology, 67, 341-349.

Lester, S., Turnley, W., Bloodgood, J., \& Bolino, M. (2002). Not seeing eye-to-eye: Differences in supervisor and subordinate perceptions of and attribution for psychological contract breach. Journal of Organizational Behavior, 23, 39-56.

Lodahl, T., \& Kejner, M. (1965). The definition and measurement of job involvement. Journal of Applied Psychology, 49, 24-33.

Makin, P. J., Cooper, C. L., \& Cox, C. J. (1996). Organizations and the psychological contract. Westport, CT: Greenwood.

Martin, T. N., \& Hafer, J. C. (1995). The multiplicative interaction effects of job involvement and organizational commitment on the turnover intentions of full- and part-time employees. Journal of Vocational Behavior, 46, $310-331$.

Mather, M., \& Nesmith, K. (2008). Arousal-enhanced location memory for pictures. Journal of Memory and Language, 58, 449-464.

Mishra, A., \& Spreitzer, G. (1998). Exploring how survivors respond to downsizing: The role of trust, empowerment, justice, and work redesign. Academy of Management Review, 23, 567-588.

Morrow, P. C. (1983). Concept redundancy in organizational research: The case for work commitment. Academy of Management Review, 8, 486-500.

Paullay, I. M., Alliger, G. M., \& Stone-Romero, E. F. (1994). Construct validation of two instruments designed to measure job involvement and work centrality. Journal of Applied Psychology, 79, 224-228.

Pfeffer, J. (1994). Competitive advantage through people: Unleashing the power of the work force. Boston: Harvard Business School Press.

Porter, L. W., Lawler, E. E., \& Hackman, J. R. (1975). Behavior in organizations. New York: McGraw-Hill.

Quinn, R., \& Shepard, L. (1974). The 1972-1973 Quality of Employment Survey. Ann Arbor, MI: University of Michigan, Institute for Social Research. 
Rabinowitz, S., \& Hall, D. T. (1977). Organizational research on job involvement. Psychological Bulletin, 84, 265-288.

Raja, U., Johns, G., \& Ntalianis, F. (2004). The impact of personality on psychological contracts. Academy of Management Journal, 47, 350-367.

Richer, S. F., Blanchard, C., \& Vallerand, R. J. (2002). A motivational model of work turnover. Journal of Applied Social Psychology, 32, 20892113.

Robinson, S. L. (1996). Trust and breach of the psychological contract. Administrative Science Quarterly, 41, 574-599.

Robinson, S. L., Kraatz, M. S., \& Rousseau, D. M. (1994). Changing obligations and the psychological contract: A longitudinal study. Academy of Management Journal, 37, 137-152.

Robinson, S. L., \& Rousseau, D. M. (1994). Violating the psychological contract: Not the exception but the norm. Journal of Organizational Behavior, 15, 245-259.

Robinson, S. L., \& Wolfe Morrison, E. (2000). The development of psychological contract breach violation: A longitudinal study. Journal of Organizational Behavior, 21, 525-546.

Rousseau, D. M. (1989). Psychological and implied contracts in organizations. Employee Rights and Responsibilities Journal, 2, 121-139.

Rousseau, D. M. (1990). New hire perceptions of their own and their employer's obligations: A study of psychological contracts. Journal of Organizational Behavior, 11, 389-400.

Rousseau, D. M. (1995). Psychological contracts in organizations: Understanding written and unwritten agreements. Thousand Oaks, CA: Sage.

Rousseau, D. M. (1998). The "problem" of the psychological contract considered. Journal of Organizational Behavior, 19, 665-671.

Rousseau, D. M. (2001). Schema, promise, and mutuality: The building blocks of the psychological contract. Journal of Occupational and Organizational Psychology, 74, 511-541.

Rousseau, D. M. (2003). Extending the psychology of the psychological contract: A reply to "Putting psychology back into psychological contracts." Journal of Management Inquiry, 12, 229-238.

Rousseau, D. M., \& Tijoriwala, S. A. (1998). Assessing psychological contracts: Issues, alternatives, and measures. Journal of Organizational Behavior, 19, 679-695.

Salancik, G., \& Pfeffer, J. (1978). A social information processing approach to job attitudes and job design. Administrative Science Quarterly, 23, 224-254.

Simon, L., Greenberg, J., \& Brehm, J. W. (1995). Trivialization: The forgotten mode of dissonance reduction. Journal of Personality and Social Psychology, 68, 247-260. 
Smith, K. J., Everly, G. S., Jr., \& Johns, T. R. (1993). The role of stress arousal in the dynamics of the stressor-to-illness process among accountants. Contemporary Accounting Research, 9, 432-449.

Stalder, D. R., \& Baron, R. S. (1998). Attributional complexity as a moderator of dissonance-produced attitude change. Journal of Personality and Social Psychology, 75, 449-455.

Staw, B. M. (1980). The consequences of turnover. Journal of Occupational Behavior, 1, 253-273.

Tekleab, A. G., \& Taylor, M. S. (2003). Aren't there two parties in an employment relationship? Antecedents and consequences of organization-employee agreement on contract obligations and violations. Journal of Organizational Behavior, 24, 585-608.

Treadway, D. C., Ferris, G. R., Hochwarter, W. A., Perrewé, P., Witt, L. A., \& Goodman, J. M. (2005). The role of age in the perceptions of politicsjob performance relationship: A three-study constructive replication. Journal of Applied Psychology, 90, 872-881.

Turnley, W. H., \& Feldman, D. C. (1998). Psychological contract violations during corporate restructuring. Human Resources Management, 37, 71-83.

Turnley, W. H., \& Feldman, D. C. (1999a). A discrepancy model of psychological contract violations. Human Resource Management Review, 9, 367386.

Turnley, W. H., \& Feldman, D. C. (1999b). The impact of psychological contract violations on exit, voice, loyalty, and neglect. Human Relations, 52, 895-922.

van Breukelen, W., van der Vlist, R., \& Steensma, H. (2004). Voluntary employee turnover: Combining variables from the "traditional" turnover literature with the theory of planned behavior. Journal of Organizational Behavior, 25, 893-914.

Wanous, J. P. (1977). Organizational entry: Newcomers moving from outside to inside. Psychological Bulletin, 84, 601-618.

Wiener, Y., Muczyk, J. P., \& Martin, H. J. (1992). Self-esteem and job involvement as moderators of the relationship between work satisfaction and well-being. Journal of Social Behavior and Personality, 7, 539-554. 